\title{
SPEECH VARIATION OF BENTENG SOMBA OPU COMMUNITY
}

\author{
Idawati Garim ${ }^{1}$, Suga Hutami ${ }^{2}$, Jusmianti Garing ${ }^{3}$ \\ ${ }^{1}$ Fakultas Bahasa dan Sastra Universitas Negeri Makassar, ${ }^{2}$ SMP Kartika IX-1 Makassar, ${ }^{3}$ Balai Bahasa Sulawesi Selatan \\ Jalan Mallengkeri, Parang Tambung, Makassar, Indonesia \\ Corresponding Author: idawati@unm.ac.id.
}

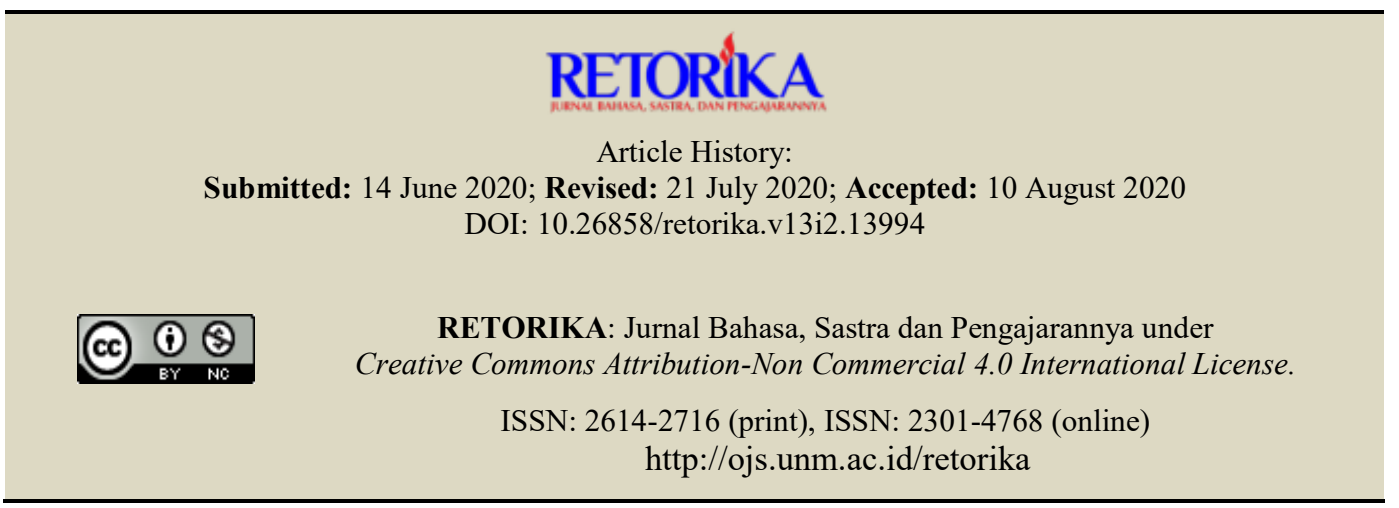

\begin{abstract}
The research aims to describe the speech variation of the Benteng Somba Opu community. The research method used is descriptive qualitative. Data were gaining from the verbal speech of the Benteng Somba Opu community in the form of dialogue. Data collection techniques conducted by doing observation and recording techniques. The data analysis carried out through data identification, data classification, data interpretation, and description of the result based on the sociolinguistics theory. The results of the research show that the Benteng Somba Opu community speech variation marked by using suffix, prefix, particle, and code-mixing. The suffix form contains $-m i,-m a,-m o,-n a,-n u,-n i,-k a,-k i,-k o,-k u,-j i,-p i,-d i,-i$, and - e. The prefix form marked by $n a-$, $k u$-, ta-, and -i. The particle seems to the words, iyo, tong, tomma (i), mako, mami, paeng, dih, and tawwa. Code mixing conveyed using the English language (off and reward), and Arabic (alhamdulillah). Those variations are adjusting with the level of social, position, age, and familiarity between the speaker and the addressee in the Benteng Somba Opu community, resulting in a good, respectful, and polite speech.
\end{abstract}

Keywords: the speech variation, sociolinguistics, Benteng Somba Opu

The language phenomenon of the speech community in South Sulawesi, particularly the Benteng Somba Opu community, is inseparable from the aspect of language use. The speech of the Benteng Somba Opu community regulated by the norms and morality prevailing in the society, not least the statement used in daily life that is still thick with the native languages of Makassar and customs that are still maintaining through now. Each speech or utterance always relates to speech components that reflect the speech community because the statement is closely related to the norms and socio-cultural values of the society.

Benteng Somba Opu community is a community that lives in the middle of the Cultural Miniature area of South Sulawesi, Gowa Regency. People who live in the Benteng Somba Opu area preserve the original language, culture, customs of Makassar, and some historical heritage results in the form of museums and traditional houses around in the location of Benteng Somba Opu. 
The community's uniqueness is not yet widely known and published by the public, especially research relating to culture, particularly the linguistic aspects that are owned by the people of Benteng Somba Opu.

Research that ever done regarding linguistics in particular language variation is "Variasi Kode dalam Tuturan Masyarakat Jawa di Gedongtataan" by Bambang Riadi; Gede Eka Putrawan (2017). This research is the dominant language codes used by the Javanese speech community in various aspects. The system found includes $\mathrm{Ba}$ hasa Jawa (BJ), Bahasa Indonesia (BI), dan Bahasa Asing. The code of BJ contains two varieties, namely krama dan ngoko variates, while the code of BA contains English and Arabic language. Code of BA, in particular, has only found in insertions to code of BJ and BI, both in the form of code-mixing and code-switching.

Another research that has conducted is "Variasi Bahasa dalam Komunikasi Komunitas Danz Base Makassar: Tinjauan Sosiolinguistik," performed by Achmad Zulakbar in 2018. This research describes language variation and the factors that cause language variations in the Danz Base community in Makassar. Language variation in the communication of the Danz Base community of Makassar is varied and understood quickly. The language variation form in the discussion of the Danz Base community of Makassar is code-mixing, interference, abbreviation, analogy, and register. Other research conducted by Rias Dwi Setiawat in 2019, titled "Variasi Bahasa dalam Situasi Tidak Formal pada Mahasiswa Program Studi Pendidikan Bahasa Indonesia di Universitas Tadulako." Results of the research find some language variations, i.e., (1) language variation in terms of the speaker, namely dialect, (2) language variations in terms of formality, namely casual differences. The factors are causing the language changes, namely: (1) the geographical and social background of the speaker, (2) the medium of conversation, and (3) the topic of discussion.

Arip Senjaya et al. conducted another research in 2018 titled "Sosiolinguistik Pemakaian Variasi Bahasa Ken (cant) oleh Para Pengemis di Lingkungan Lampu Merah Kota Serang, Provinsi Banten." The research result shows that 15 vocabularies are consisting of nouns, verbs, phatic particles, and transformation tools vocabulary. Those vocabularies are categorized as a characteristic of Ken language variation and classified as a marker of Ken language features. The latest research concerning language variation is written by Usnia Wati et al. in 2020. The study is "Variasi Bahasa pada Mahasiswa Perantau di Fakultas Ilmu Budaya Universitas Mulawarman: Kajian Sosiolinguistik. The results convey that the language used by overseas students at this university varies, and social and situational factors cause the variation.

Based on the research result that has been conducting, it is clear that the research regarding speech variation in the Benteng Somba Opu community in terms of sociolinguistics view has never studied yet. Thus, researchers are interested in conducting this study to reveal and find out what this community uses variations in speech. It is also the core problem of this study.

Language variation is the study involving sociolinguistics because it includes social aspects or speech community. Mirian Meyerhoff (2011:1) stated that sociolinguistics is the study that was talking about social and linguistics. Furthermore, Chaer dan Agustina (2010:3) conveyed that sociolinguistics is the study of the characteristics of language variation, the function of language variation, and language usage. Those three elements interact and change each other in the speech community, the social identity of the speaker, and the social environment in which the speech event occurs, and the varying degrees of linguistics. It is caused by the social dimension that gives meaning to language and creates a variety of styles.

Language diversity arises due to the variety of cultures, races, and ethnicities in Indonesia that have created various languages used as a means of communication between members of the community. The condition makes Indonesian people as bilingual and multilingual. It is in line with Poedjosoedarmo (1985:526) view that Indonesian people are mainly a bilingual society. The linguistic situation triggered by the use of two or more languages, namely the local language as a mother tongue (first language) and Indonesian as a second language (national language).

Language diversity, or known as language variation, is language usage according to the user. Language-based on the user divided into four varieties, i.e. (1) language variation in terms of the speaker, (2) language variation in terms of the user, (3) language variation in terms of formality, and (4) language variation in terms of facilities aspects (Chaer and Leonie Agustina, 2010:83).

Language variation in terms of the speaker consists of four, namely, idiolect, dialect, 
kronolek, and sociolect. Language variation in terms of the user is related to the user or its function called function, variety, or register. Then, language variation in terms of formality based on the level of formality. Language varia-tion in terms of facilities aspects means verbal range and written variety. The form of oral variety is a telephone. Meanwhile, written variety is telegraphic. Martin Joss in (Chaer and Agustina 1995:92) divided language variation into five types, namely formal, informal or casual variate, and relaxed variety or close friends when resting, exercising, or recreation, etc.)

The language variations arise in a social community with a culture and own social life. They have a unique form, meaning, and function, which is implementing community life itself. The purpose of this research is to find out the types of speech variation of the Benteng Somba Opu community. Thus, the public, researchers, academics, and students can understand the differences in the speech form of the Somba Opu community. The results of this study can use as reference material in conducting further investigations.

\section{METHOD}

The research used is qualitative research with a descriptive design. Mardoyo (2008:65) argued that descriptive-qualitative is the research of data collected and expressed in the form of words arranged in sentences, for instance, convictions resulting from interviews between researchers and informants. Data was collected directly in the field, observing and recording conversations (in the form of natural dialogue) according to the speech events in their daily lives.

The research locates in the Gusung Sarombe, the Benteng Somba Opu, Gowa Regen-cy, South Sulawesi. This location is an area where native speakers of the Makassar dialect live, so researchers believe that the authenticity and validity of the data can be account for. The focus of this research is the speech of the Gusung Sarombe community, Sub-district of Benteng Somba Opu, in terms of speech variations in the Benteng Somba Opu community. The data in this study are verbal speech or conversation in the form of dialogue of society in the Gusung Sarombe environment, the sub-district of Benteng Somba Opu, and the Gowa Regency. Then, the source of this research data is the people in Gusung Sarombe,
Benteng Somba Opu, who have different professions. Some of them work as housewives, traders, entrepreneurs, employees, students, teachers, and individual social groups such as majelis taklim. The number of informants consists of 3 to 4 people depending on the situation the speech occurs. The chosen informants are due to they are native speakers of the Makassarese language and are still very fluent in speaking the Makassarese language.

The main instrument of research is the researchers. The researchers go directly to the speaker and chats and state the researcher's aims and objectives. Then, researchers recorded their conversation in the form of dialogue. After their discussion completed, the researchers asked several things, such as their name, address, age, gender, occupation, and native language. The data is complementary in the data collection process. After the data was collected, it was analyzed using the sociolinguistics theory proposed by Chaer and Agustina (2010: 83). The data analysis stages used were (1) identifying variations in speech utterances from the people of Benteng Somba Opu, (2) classifying forms and varieties of speech, (3) interpreting data, and (4) describing the results.

\section{FINDINGS AND DISCUSSION}

\section{Findings}

\section{Speech Variation in the Benteng Somba Opu Community}

The result finds that the speech variation used by the Benteng Somba Opu community based on the Makassar dialect, which featured by using the markers of suffixes, prefixes, particles, and codes-mixing. Those markers are $-m i$, $-m a$, $m o,-n a,-n u,-n i,-k a,-k i,-k o,-k u,-j i,-j a,-p i,-d i$, $-i$, and -e. Suffixes marker are -mi, $-m a,-m o,-n a$, $-n u,-n i,-k a,-k i,-k o,-k u,-j i,-j a,-p i,-d i,-i$, and $e$. Prefixes marker are $n a-, k u-, t a-$, and $-i$. Furthermore, particles marker are iyo, tong, tomma, and mako. While, the code-mixing is markered from the Indonesian language to the Makasarese language, Indonesian language to the English language, and Indonesian language to the Arabic language. This code-mixing is off, reward, and alhamdulillah. The speech variation can see at the following data: 


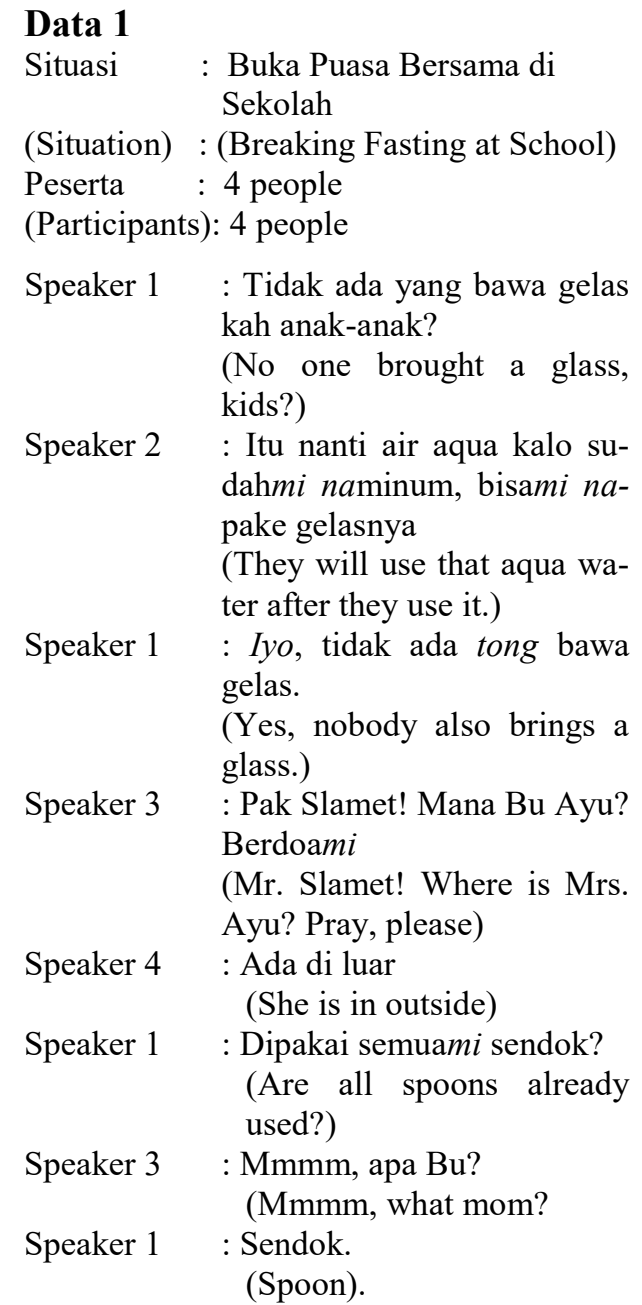

Data (1), is talking of breaking fasting at school. There are four speakers to be informants, namely $\mathrm{P} 1, \mathrm{P} 2, \mathrm{P} 3$, and $\mathrm{P} 4$. The four informants used speech variation of Makassar dialect in communicating. It marked by using dialect $-m i$, $n a-$, iyo, and tong. It means that the Somba Opu community used Makasarese dialect of Indonesian speech or referred to as code-mixing. This combination creates a Makassar accent that classified as unique. Unique because in arranging sentences added by prefixes and suffixes. The speakers in this context also paid attention to whom they speak. The above speech background cleared that the speaker and the addressee are colleagues. Thus, they used the word iyo as a form of familiarity and in a relaxed speech situation. Besides this word, there is also the use of particles in the Makassarese language, such as tong. The particle has meant more than one depending on the sentence used or following it.

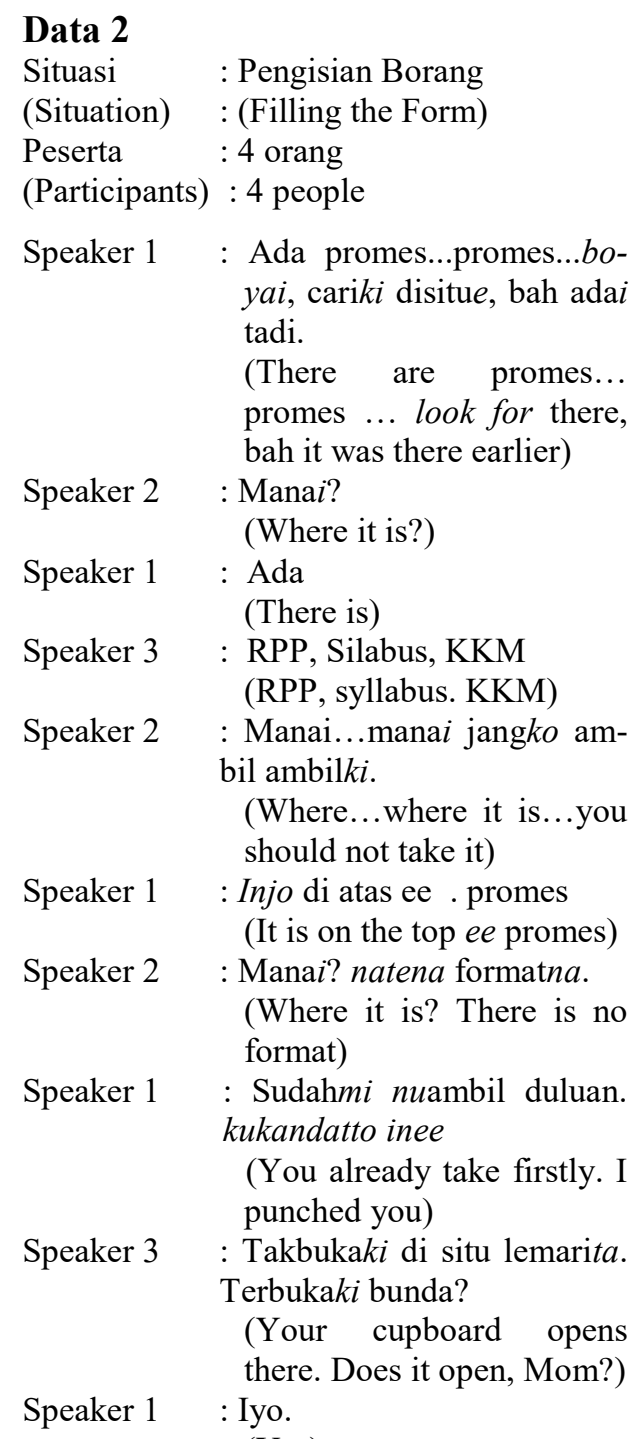

(Yes).

Data (2) consists of four speakers who speak of filling the form at school. The dialogue seems that the speaker and the addressee use the Makassar dialect through the markers of suffixes $-i, \quad-e, \quad-k i, \quad-k o, \quad-m i, \quad-n a,-n u$ prefixes $k u$ - and $t a$-. The speech variation uttered by $\mathrm{P} 1, \mathrm{P} 2, \mathrm{P} 3$, and $\mathrm{P} 4$. In addition to using these markers, speakers also use the Makassar dialect, namely, boyai, natena, cariki, kandatto, and inne. The word kandatto uses to be pronounced by speakers ( $\mathrm{P} 1)$ to the addresses as a form of jokes and familiarity with other teacher colleagues. While firmly asking for the semester program and asking to find promes note that was lying on the table, as well as the completeness of other supervision files to other fellow teachers. 
The variations of the Makassar language used to indicate an informal and relaxed situation.

\begin{tabular}{|c|c|}
\hline \multicolumn{2}{|l|}{ Data 3} \\
\hline Situasi & $\begin{array}{l}\text { Rekapan Barang Restoran } \\
\text { GDP }\end{array}$ \\
\hline (Situation) & $\begin{array}{l}\text { : (Goods Recap at GDP Res- } \\
\text { taurant) }\end{array}$ \\
\hline $\begin{array}{l}\text { Peserta } \\
\text { (Participants) }\end{array}$ & $\begin{array}{l}: 3 \text { orang } \\
: 3 \text { people }\end{array}$ \\
\hline Speaker 1 & $\begin{array}{l}\text { Mana Mira, ekstra off! } \\
\text { bagaimanaji kemarin tidak } \\
\text { adaji yang salah stoknya? } \\
\text { (Where is Mira, extra off! } \\
\text { how was it yesterday, did } \\
\text { not have the wrong stock?) }\end{array}$ \\
\hline Speaker 2 & $\begin{array}{l}\text { Ya tidak tauka Muli. } \\
\text { (Yes, I did not know too, } \\
\text { Muli.) }\end{array}$ \\
\hline Speaker 1 & $\begin{array}{l}\text { Bagaimana stoknya kemarin } \\
\text { Muli? } \\
\text { (How was the stock yester- } \\
\text { day, Muli?) }\end{array}$ \\
\hline Speaker 2 & $\begin{array}{l}\text { : Muli, ditanyako! } \\
\text { (Muli, you are asked!) }\end{array}$ \\
\hline Speaker 1 & $\begin{array}{l}\text { Bagaimana stoknya kemarin } \\
\text { sore, maksudku klop se- } \\
\text { mua? } \\
\text { (How was the stock in yes- } \\
\text { terday noon, I mean, all was } \\
\text { fit?) }\end{array}$ \\
\hline Speaker 3 & $\begin{array}{l}\text { Ini sekarang kulanjutki sean- } \\
\text { dainya bisa malam Jumat, } \\
\text { malam Jumatpi. } \\
\text { (I would continue it now if } \\
\text { it could be Friday night.) }\end{array}$ \\
\hline Speaker 2 & $\begin{array}{l}\text { : Tinggal dia pindahkan ke } \\
\text { buku stok baru } M b a \text {. } \\
\text { (He just moved it to the new } \\
\text { stock book, } M b a \text { ) }\end{array}$ \\
\hline Speaker 1 & $\begin{array}{l}\text { Alhamdulillah selama tidak } \\
\text { adami yang minus. Kak } \\
\text { Rahma memang top se- } \\
\text { bagai pendamping untuk } \\
\text { sementara. } \\
\text { (Alhamdulillah, so far, the- } \\
\text { re is no minus again. Kak } \\
\text { Rahma is a top as a com- } \\
\text { panion for a while.) }\end{array}$ \\
\hline
\end{tabular}

Data (3) is talking about goods recap at GDP restaurant. The above speech uses the variation of the Makassar dialect. Another variation in the statement is the use of foreign languages, namely English and Arabic. Variety of Makassarese language seems to the markers of suffixes and prefixes, i.e., $-j i,-k a,-k o,-k u,-k i,-p i,-m i$, and $k u$-. English usage is off, and Arabic is alhamdulillah. In addition to the use of variations in these languages, there are also affix errors in the word Mba. The name Mba should be Mbak. The arising of those variations is due to the bilingual speakers. The speech occurs in a familiar and respectful situation marked by using suffixes $k o$ - as familiarity form and prefix $-k i$ as respect for elders.

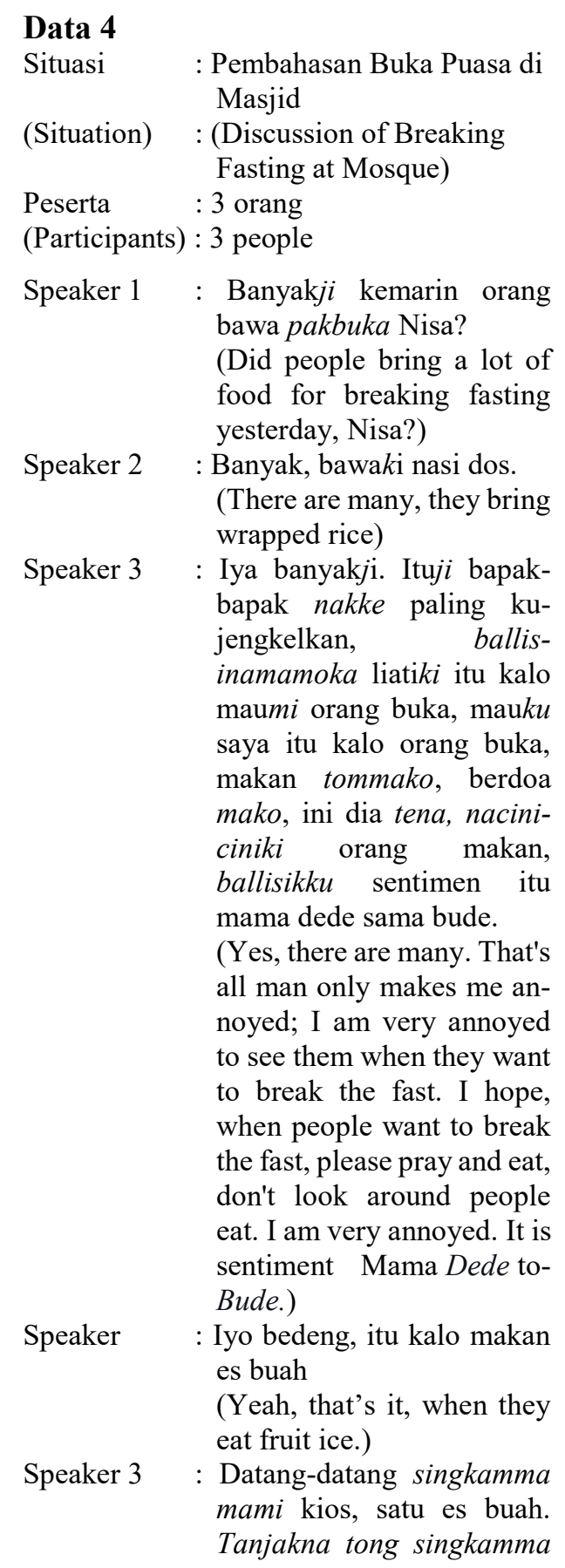




$\begin{array}{ll} & \text { mami karaeng lompo, ap- } \\ & \text { pala mami es buah. Ikauji } \\ \text { pata masigi. } & \text { (They come like coming } \\ & \text { into the stall, one fruit ice. } \\ & \text { Like a big man, ask for fruit } \\ & \text { ice. Indeed, you only have a } \\ & \text { mosque?) } \\ \text { Speaker 1 } \quad \text { Itu kalo datang menyero- } & \text { botki. } \\ & \text { (When they come, they just } \\ \text { grabbed) } & \text { Iyo baru selalu bedeng bawa } \\ \text { kantong ta'tiga, nabilang } \\ \text { Tasya. } \\ \text { (Yes, they always carry } \\ \text { three bags, Tasya said.) }\end{array}$

The above data (4) discusses breaking fasting at the mosque. There are three speakers, i.e., $\mathrm{P} 1, \mathrm{P} 2$, and $\mathrm{P} 3$. P1 asks to $\mathrm{P} 2$ regarding the food that people brought for breaking fasting yesterday. In the speech, speakers pay attention to who the speaker is talking to and the context of the rhetoric used in the Indonesian language and Makassarese language context. However, in the above speech, the variation of the Makassar dialect is more dominant than the Indonesian language. Variety of Makassar dialect seems at using suffixes, such as $-j i,-k i,-m i,-k u,-k o$, and prefixes $n a-, i-, t a-$, and $n a-$. Those suffixes and prefixes have each meaning according to the speech context. In addition, other speech variations in the Benteng Somba Opu community are particles that use the Makassar dialect, namely tong, tomma, and mako. These particles have functioned as an affirmation of the speech.

Furthermore, the speech above clearly seen the use of code-mixing from the Indonesia language to Makassarese language. Then, the speech situation occurs in a relaxed condition. Between the speaker and the addressee are members of the recitation assembly. Thus, they use the suffix $-k i$, which then changes to the suffix $-k o$, and is emphasized by the word iyo as a form of familiarity.

$\begin{array}{ll}\begin{array}{l}\text { Data 5 } \\ \text { Situasi } \\ \text { (Situation) }\end{array} & \begin{array}{l}\text { : Pemeriksaan di Puskesmas } \\ \text { (Medical at Public Health }\end{array} \\ \text { Peserta } & \text { Center) } \\ \text { (Participant) } & : 3 \text { people } \\ \text { Speaker 1 } & \begin{array}{l}\text { : Ibu, naperiksa apaki? Ki- } \\ \text { rea nipareksa? Anatta? }\end{array}\end{array}$

(Mom, what did he check? Which one checked? Your child?)

Speaker 2 : Iye

(Yes)

Speaker 1 : Naparessa apai, poli (What did he check, general poly?)

Speaker 2 : Batuk-batuki

(She coughed)

Speaker 3 : Oh batuk-batuki (Oh, she coughed)

Speaker 1 : Mempomaki rong di' (Please have a seat first)

Speaker 3 : Ditambingi rong. Kei arenna?

(She is on the list first. What is her name?)

Speaker $1 \quad$ :Mempomaki

(Have a seat)

Speaker 3 : Kupawwangi rong dokterka di'

(I will ask the doctor first)

Speaker 1 : Niaji dokterka lalangi.

(The Docter is inside).

The main topic at the data (5) is medical health at Public Health Center. The situation of the speech uttered by three speakers, i.e., P1, P2, and P3. P1 uses Makasserese language to P2 by asking Mom, what did he check? Which one checked? Your child? The speech is a form of servicing to patients using Makassar language, which is polite and friendly, then P2 is also answered politely. It is commonly done by $\mathrm{P} 1$ who speaks Makassar because people who come to the health center for treatment in their daily lives, communicate more fluently using the Makassar language than Indonesian. It means that the speaker prefers to use Makassarese language than Indonesian when they met among them.

It is also clear that markers $-k i,-n i,-n a,-d i$ ' $k a$, $-t a$, and rong feature the variations of the Makassar dialect used in the utterances. In the speech, speakers use the Makassarese language to the addressee politely. Polite discourse marks using the suffixes $-k i$, and $-t a$, which is a form of respect in the Makassarese language. This speech's situation occurs in an office, namely at the health center, so that the statement that occurs in a formal case.

\section{Data 6 \\ Situasi : Membeli Sayur (Situation) : (Buying Vegetables)}


Peserta : 4 orang

(Participants) : 4 people

Speaker 1 : Ta' berapa inie?

(How much is this?)

Speaker 2 : Ta'berapa ini daeng e, pepayayya?

(How much is papaya, Daeng?)

Speaker 3 : Pepaya, semangka ada (Pepaya, only watermelon is there)

Speaker 4 : Kasihka ini daeng lombokta Rp 2.000

(Daeng, give me this chili Rp 2000)

Speaker 1 : Itu ada sayur kelor, mauki bu?

(There are moringa vegetables, do you want Mom?)

Speaker 4 : Jangan saiki kasih mahalmahal daeng

(Please don't make it expensive, Daeng.)

Speaker 2 : I Daeng sangnging ka'jala mami

(Daeng, everything is only expensive.)

Speaker 1 : Di Daeng Tarring Rp. 2.000, banyakna mamo lombokna (Daeng Tarring Rp. 2000, you have many chilies)

Speaker 3 : Ka banyak tawwa inie, hampir penuh kantong. Sayur sawi cantik.

(That's a lot, and it is almost full of the sac. The mustard green is beautiful.)

Speaker 4 : Ada sayur bayam?

(Do you have spinach?)

Speaker 3 : Habismi sayur daun-daunku. Daun bayam, daun kacang habis, tinggal sawi-sawi mami. Nah itu enak sama mie, campur mie goreng boleh, ditumis juga boleh.

(My leafy vegetables run out. Spinach and peanut leaves run out; only the mustard green is ready. Well! It will good with mustard green mixed by fried noodles. It sautéed will be good taste also)

Speaker 4 : Daun kelor?

(Moringa vegetables?)

Speaker 3 : Buah kelor juga ada

\begin{tabular}{|c|c|}
\hline & $\begin{array}{l}\text { (Moringa fruit is also avail- } \\
\text { able.) }\end{array}$ \\
\hline Speaker 4 & $\begin{array}{l}\text { : Tomatta? } \\
\text { (Tomato?) }\end{array}$ \\
\hline Speaker 3 & $\begin{array}{l}\text { : Habis tomatta } \\
\text { (Tomatoes sold out) }\end{array}$ \\
\hline Speaker 4 & $\begin{array}{l}\text { : Ini berapa satu? } \\
\text { (How much is this?) }\end{array}$ \\
\hline Speaker 3 & $\begin{array}{l}\text { Seribuji satu itu kangkong } \\
\text { (Kangkung is only a thou- } \\
\text { sand for one.) }\end{array}$ \\
\hline Speaker 4 & $\begin{array}{l}\text { : Kasihma dua ini } \\
\text { (Give me two this.) }\end{array}$ \\
\hline Speaker 3 & $\begin{array}{l}\text { : Tuing-tuing } \\
\text { (Tuing-tuing) }\end{array}$ \\
\hline Speaker 1 & $\begin{array}{l}\text { : Apalagi dibeli ini baik } \\
\text { (Well, what is again to buy) }\end{array}$ \\
\hline Speaker 4 & $\begin{array}{l}\text { Gambasta, tua ini kah? } \\
\text { (did your squash run out?) }\end{array}$ \\
\hline Speaker 3 & $\begin{array}{l}\text { Muda semua, ambil semua? } \\
\text { (All are young, do you want } \\
\text { all?) }\end{array}$ \\
\hline Speaker 4 & $\begin{array}{l}\text { : Rp } 3.000 \text { mo } \\
\text { (Just give me Rp. 3.000) }\end{array}$ \\
\hline Speaker 4 & $\begin{array}{l}\text { : Berapa? Rp 3.000? } \\
\text { (How much? Rp 3.000? }\end{array}$ \\
\hline Speaker 3 & $\begin{array}{l}\text { Enak ini sama mie, mie } \\
\text { goreng juga boleh. } \\
\text { (It will be delicious with } \\
\text { noodles, in particular, fried } \\
\text { noodles.) }\end{array}$ \\
\hline Speaker 1 & $\begin{array}{l}\text { : Ih diapai? } \\
\text { (Oh, how to make it?) }\end{array}$ \\
\hline Speaker 2 & $\begin{array}{l}\text { : Diiris tipis-tipiski tolo } \\
\text { (Just thinly sliced) }\end{array}$ \\
\hline Speaker 4 & $\begin{array}{l}\text { : Berapami itu Daeng? } \\
\text { (How much is this, Daeng?) }\end{array}$ \\
\hline Speaker & $\begin{array}{l}: \operatorname{Rp} 7.000 . \\
(\operatorname{Rp} 7.000 .)\end{array}$ \\
\hline
\end{tabular}

There are four speakers at the above data (6). The topic is buying vegetables. The speakers use the Makassar dialect to the addressee when dialogue happens. The speech shows the speech variation of the Makassar dialect. The variations featured by suffixes marker $-t a$ ', $-k a,-k i$, -na, $m o,-m a,-m i$, and $-i$. The Benteng Somba Opu community is using more Makassar dialect mixed the Indonesia language when doing bargaining. It means that the people of Benteng Somba Opu still have a positive attitude towards their language. It makes the Makassarese language, particularly the Makassar dialect in Benteng Somba Opu, still exists because speakers use Makassarese language more than other languages. 


\section{Data 7}

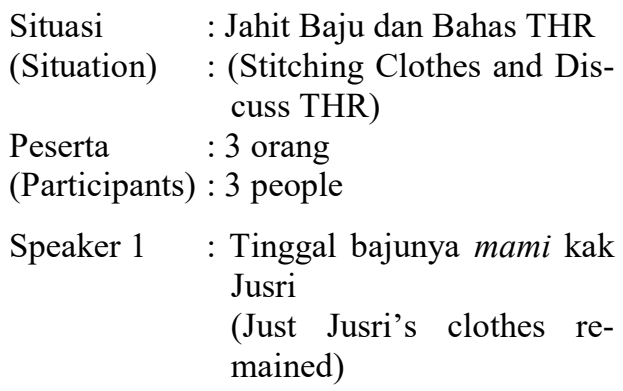

Speaker 2 : Kenapa tongi dia, menjahit tongi, mau tommi lebaran? (What's wrong with him. He sews too; it is already Eid also?)

Speaker 1 : Ohh 2 bulan yang lalu dia masuk tommi kainnya. (Oh, he put his cloth two months ago.)

Speaker 2 : Oh ada tong kainnya

(Oh, there is also his cloth.)

Speaker 1 : Nabilang bulan 6 pi saya, baiklah

(He said, just in June for me, okay.)

Speaker 2 : Mau?

(Do you want?)

Speaker 1 : Kebayaji. Samai Wati. Tapi nabilang Wati, mau memangmi kupake itu kak, tapi bajunya Wati selesaimi.

(Only Kebaya. Same with Wati. However, Wati said, I want to use it already, but Wati's clothing finished.)

Speaker 2 : Ternyata tidak dapatki paeng THR kak Jusri dih? (The fact, Kak Jusri is not getting THR.)

Speaker 1 : Ih masa?

(Oh, really?)

Speaker 3 : Tidak terlalu anuja saya kalo lebaran, rewardnya ji kusuka

(I am not really when Eid coming; I only like its rewards.)

Speaker 2 : Tidak dapatki bedeng, biar natal, kan $k u$ kira tidak dapat dia lebaran

(He said he could not find it the same when Christmas, I think he does not get Eid.)

Speaker 1 : Oh, bisanya itu

(Oh, how come)

Speaker 3 : Tidak tolerenki kalo begitu tawwa
(He is intolerant, right?)

Speaker 2 : Tidak pernah bedeng dapat. He never gets)

Data (7) tells about stitching and THR. The speakers consist of three people who coded by P1, $\mathrm{P} 2$, and $\mathrm{P} 3$. The speakers use speech variation in the form of Makassar dialect and code-mixing, namely the Indonesian to Makassarese language and the Indonesian to the English. Besides, using the Makassar dialect and code-mixing, it is also using particles to emphasize their statements. Makassar dialect seems to the usage of suffixes $p i,-j i,-m i,-j a,-k i$, and $-i$ as well as prefixes $n a-$ , and $-k u$. The usage of code-mixing appears in the English language, i.e., reward. Furthermore, particles featured with words mami, tong, tommi, paeng, dih, and tawwa. Based on the speech variations used by the Benteng Somba Opu community, as seen at data (7), clarifies that the utterances occur in an informal situation and uses familiar and relaxed language.

\section{Discussion}

\section{Speech Variation in Benteng Somba Opu Community}

The results of the research concluded that speech variations of the Benteng Somba Opu community based on the speech situation at the speech community that can affect the way a speaker speaks to the addressee in an environmental context. Therefore, the social environment dramatically affects the process of interaction when doing communication. In other words, the continuity of interaction in one or more utterances involves two or more parties with one central statement, at a particular time, place, and situation.

Speech variations used by the Benteng Somba Opu community are the Indonesian language that has a Makassar dialect. The dialect is markers adding in the form of suffixes and prefixes. Suffixes are $-m i,-i,-e,-k i,-k o,-m i,-n a$, $n u$, and prefixes are $n a-, k u$-, and $t a$-. In addition to suffixes and prefixes form, there is also a marker in the form of particles that emphasize the Makassar dialect, namely iyo and tong. Another variation that exists in the speech of the Benteng Somba Opu community is code-mixing form, such as boyai, natena, cariki, kandatto, inne, off, and alhamdulillah. These variations directly 
used in the speech of Makassar dialect with the Indonesian language, the English, and the Arabic. It means that the code-mixing in the speech of the Makassar dialect of the Benteng Somba Opu community is also happening. It is due to the speakers of the Benteng Somba Opu community is bilingual. This finding is according to the theory conveyed by Poedjosoedarmo (1985:526) that the Indonesia community is mostly a bilingual society. The linguistic situation triggered by the use of two or more languages, namely the regional language as the mother tongue (first language) and Indonesian as the second language (national language).

The speech variations used by the Benteng Soba Opu community happen in the informal and formal environment situation. This finding also proves the theory of Chaer and Agustina (1995: 92), who conveyed that language variation can be happening in casual and formal situations. This situation is working well on this research result.

The fact happening in this speech of the Benteng Somba Opu community is if a statement occurs in a formal environment, the speaker and the addressee use excellent and polite or standard language. Conversely, if speech occurs in an informal situation, the speaker and the addressee do not use standard language but use the familiar and relaxed style. In this case, the language used in a casual and informal situation is the Makassarese dialect. The view is similar to what expressed by Halliday and Hasan (1994: 56) that dialect is a variation of language based on the user. The other words, dialect, commonly used by the user, is depending on who the user is, where the user comes from, while the register is the language used today, depending on what is done and the nature of the activity. Halliday and Hasan's statement is very relevant to the findings in the research that the use of the Makassar dialect is identical to the user or user of the language or dialect itself, namely the Makassar dialect and is supported by the situation of the speaker and the addressee in a friendly and relaxed position.

The results of this research support the results of the previous study. One of the research conducted by Hasyim, M (2008), namely "Faktor Penentu Penggunaan Bahasa pada Masyarakat Tutur Makassar: Kajian Sosiolinguistik di Kabupaten Gowa." The results of the research are (1) the language skills of the speaker and the addressee, if the speaker cannot use BI, then he uses
$\mathrm{BM}$ or $\mathrm{BMM}$; (2) the proper place and situation use $\mathrm{BI}$ and $\mathrm{BM}$, while the non-official place and situation use BM and BMM; (3) the participant in the interaction, if the person invited to talk is a close friend or family member, then he uses BM, but if he does not know each other, then he uses $\mathrm{BI}$ or BMM; (4) the function of the intention and will of the speech is if the objective is to preserve their culture, to teach, and to bid them, they use $\mathrm{BM}$ or BMM, however, if they intend to keep their identity secret, criticize, have rumors, and confirm, they use BI or BMM.

Furthermore, the research conducted by Apriani (2014) titled "Pemilihan Bahasa oleh Mahasiswa Asing di Perguruan Tinggi Kota Bandung (Kajian Sosiolinguistik)." The results know speech components that affect the language choices of international students and the form of code variations and functions of each language that appear in the speech and writing of international students in the research.

The two studies have something in common: investigating the variations in how and why the language used, and there is a consideration of the language use that is often used in daily life as a form of social culture. The researcher's research to describe the Benteng Somba Opu community has been done by the researcher to describe the speech variation used by this community. The study regarding language variation used by speakers of Benteng Somba Opu found language variation from a group of speakers or a language community with a relative number, which is in a particular place or area. The use of the dialect conditioned with whom of the language society doing communicates. If the addresses use the Makassarese language, the speakers will also use the Makassar dialect in conveying the intent and purpose of their speech. It is done to adjust themselves with whom the speaker is speaking.

\section{CONCLUSION}

Summing up the findings and discussion, it concluded that the Benteng Somba Opu community's speech variations use the Makassar dialect when speaking. Between the speaker and the addressee speak to each other using the Makassar dialect marked by suffixes and prefixes. Suffixes form are -mi, -ma, -mo, -na, -nu, -ni, -ka, -ki, -ko, $-k u,-j i,-j a,-p i,-d i,-i$, and $-e$. While prefixes form are $n a-, k u-, t a-$, and $-i$. Those markers are 
in accordance with the level of social relation, position, age, and familiarity of the speaker with the addressee, such as the use of markers - $k o$ is used to the addresses who are the same age or co-workers, while the marker - $k o$ will change to $-k i$ when the addressee is an older person. Next, the Indonesian language variation used when the speaker and the addressee are unable to communicate in the Makassarese language, so they use Indonesian, so it is also seen using code-mixing in speech events in the Benteng Somba Opu community. The code-mixing seems in the English and the Arabic. The English are using of the word off, reward, and the Arabic is the

\section{REFERENCES}

Achmad, Z. (2018). Variasi Bahasa dalam Komunikasi Komunitas Danz Base Makassar: Tinjauan Sosiolinguistik. Skripsi. Makassar: Universitas Hasanuddin. http://digilib.unhas.ac.id/uploade d_files/temporary/DigitalCollection/MmIwY mQ1YTcxMWRkZDgyMmZkNjAzYWI2ODRkYmMwZjE0ZWZjZjVmZQ==.pdf.

Apriani. (2014). Pemilihan Bahasa oleh Mahasiswa Asing di Perguruan Tinggi Kota Bandung (Kajian Sosiolinguistik) http://repository.upi. edu/14097/1/S IND 1006529 Title.pdf.

Arip, S., Dkk, (2018). Sosiolinguistik Pemakaian Variasi Bahasa Ken (cant) oleh Para Pengemis di Lingkungan Lampu Merah Kota Serang, Provinsi Banten. Jurnal Membaca, Bahasa dan Sastra. 3. (2): 111-118. http://dx.doi.org/10. 30870/jmbsi.v3i2.5224

Bambang, R. \& Gede E. P. (2017). Variasi Kode dalam Tuturan Masyarakat Jawa di Gedongtataan. Jurnal AKSARA 18 (1): 63. http://jurnal.fkip. unila.ac.id/index.php/aksara/article/view/135 88.

Chaer, A. \& Leoni A. (1995). Sosiolinguistik: Suatu Pengantar. Jakarta: Rineka Cipta.

Chaer, A. \& Leoni A. (2010). Sosiolinguistik Perkenalan Awal. Jakarta: Rineka Cipta.

Fishman, J.A. (2010). Sociolinguistics--- A Brief Introduction. Massachusetts Newbury House Publishers.

Halliday \& Hasan. (1994). Bahasa, Konteks, dan Teks; Aspek-aspek Bahasa dalam Pandangan Semi- word alhamdulillah. The usage of code-mixing indicates that the speakers of the Benteng Somab Opu community are bilingual. However, the use of the Makassar dialect still dominated its usage when speaking even though it is already using Indonesian. In addition to marker and code-mixing used by this community, it is also used particles in Makassar dialect, namely iyo, tong, tomma (i), mako, mami, paeng, dih, and tawwa. Particles function as affirmations in the context of sentences that uttered by the Benteng Somba Opu community.

otik Sosial. Yogyakarta: Gajah Mada University Press.

Hasyim, M. (2008). Faktor Penentu Penggunaan Bahasa pada Masyarakat Tutur Makassar: Kajian Sosiolinguistik di Kabupaten Gowa. Jurnal Humaniora. 20 (1): 75-88. https://doi.org/10. 22146/jh. 921 .

Mardoyo. (2008). Kinerja Kepala Sekolah SMA Negeri 1 Klaten dalam Implementasi Manajemen Berbasis Sekolah. Tesis. Program Pascasarjana Universitas Muhammadiyah Surakarta. (Online) (www/damandiri.or.id) diakses tanggal 26 Februari 2018.

Miriam, M, (2011). Introducing Sociolinguistics. Second Edition. New York: Routledge Press.

Poedjosoedarmo, S. (1985). Komponen Tutur. Jakarta: Penerbit Arean.

Rias, D. S. (2018). Variasi Bahasa dalam Situasi Tidak Formal pada Mahasiswa Program Studi Pendidikan Bahasa Indonesia di Universitas Tadulako. Jurnal Bahasa dan Sastra 4 (1): 1-11. http://jurnal.untad.ac.id/jurnal/index.php/BDS /article/view/12245http://jurnal.untad.ac.id /jur nal/index.php/BDS/article/view/12245/9538.

Usnia W., Dkk. (2020). Variasi Bahasa pada Mahasiswa Perantau di Fakultas Ilmu Budaya Universitas Mulawarman: Kajian Sosiolinguistik. Jurnal Ilmu Budaya, 4(1): 23-37. http://dx. doi.org/10.5281/ilmubudaya.v4i1.2559 